\title{
Sperm concentration influences the post-thaw livability of frozen goat semen
}

\author{
Edeneil Jerome P. Valete ${ }^{1,3}$, Lerma C. Ocampo ${ }^{1,3^{*}}$, Flocerfida P. Aquino, ${ }^{1}$ Kristina J. Cruz $^{3}$ and Marlon B. \\ Ocampo $^{1,2}$
}

${ }^{1}$ Philippine Carabao Center - Reproductive Biotechnology Unit, Science City of Muñoz, Nueva Ecija; ${ }^{2}$ College of Veterinary Science and Medicine, Central Luzon State University, Science City of Munoz, Nueva Ecija; ${ }^{3}$ Department of Biological Sciences, Central Luzon State University, Science City of Muñoz, Nueva Ecija, Philippines 3120

Article history

Received: 23 May, 2016

Revised: 20 Jun, 2016

Accepted: 22 Jun, 2016

\begin{abstract}
In this study, goat semen was cryopreserved in a reduced concentration of $75 \times 10^{6}$, $50 \times 10^{6}$ and $25 \times 10^{6} \mathrm{sperm} / \mathrm{ml}$ and evaluated based on post-thaw motility and livability. The ejaculated semen samples were collected using an artificial vagina, extended with an egg yolk Tris extender, cryopreserved in straws using glycerol (7\%) and egg yolk $(5 \%)$ as permeating and non-permeating cryoprotectants in $\mathrm{LN}_{2}$. Post-thaw semen evaluation showed motility scores of $36.6 \pm 2.13 \%, 35.4 \pm 2.04 \%, 27.0 \pm 3.0 \%$ and $19.2 \pm 2.78 \%$ for the control, T-A $\left(75 \times 10^{6}\right)$, T-B $(50 \times 106)$ and T-C $\left(25 \times 10^{6}\right)$, respectively. The mean post-thaw percentage livability obtained in the control $(60.6 \pm 4.39)$ was higher than T-A $(42.86 \pm 1.83)$, T-B (39.36 \pm 2.86$)$ and T-C $(19.2 \pm 5.27)$. The percentage abnormal sperm in all treatment groups were less than $10 \%$, indicating that the method used for freezing of goat semen in reduced concentration could be useful in artificial insemination and in vitro fertilization studies. The reduced sperm motility and livability after thawing merits further studies on the factors influencing the survivability of sperm during cryopreservation in creating a standardized and better freezing protocol for goat semen.

Keywords: Cryopreservation; livability; motility; semen
\end{abstract}

To cite this article: Valete EJP, Ocampo LC, Aquino FP, Cruz KJ and Ocampo MB, 2016. Sperm concentration influences the post-thaw livability of frozen goat semen. Res. Opin. Anim. Vet. Sci., 6(5): 158-164.

\section{Introduction}

Commercial goat raising in the Philippines using introduced breeds such as Anglo Nubian, Boer, Saanen, Alpine and Toggenberg is gaining popularity and wide acceptance within the local small ruminant industry. As a result, there has been an emergence or renewed interest in artificial insemination using goat semen either in liquid/extended form or with the use of frozen goat semen. In addition to use processed liquid or extended goat semen for artificial insemination, frozen semen from genetically superior sperm donor can be stored in cryo-conservation in vitro for Animal Genetic Resources Cryobanking. One recent development is the optimized goat semen cryopreservation procedure using Tris-citric acid, fructose and raffinose-based semen extender with 5\% egg yolk and 7\% glycerol (Beltran et al., 2013). In this study, a sperm concentration of frozen semen at $100 \times 10^{6}$ resulted in live birth after artificial insemination of recipient does.

The volume of ejaculated goat semen is fairly small when compared to other livestock species such as

*Corresponding author: Lerma C. Ocampo, Philippine Carabao Center - Reproductive Biotechnology Unit, Science City of Muñoz, Nueva Ecija; E-mail: ocampolerma040661@gmail.com 
cattle, buffalo and pigs. Semen volume ranges from $0.5-1.5 \mathrm{ml}$ per ejaculate with a sperm motility of about $70-85 \%$ and a sperm concentration 2.5-5.0 $\times 10^{9}$ $\mathrm{sperm} / \mathrm{ml}$. Therefore, the relatively minute volume of sperm ejaculate when processed into frozen semen can produce very few numbers of semen straws if the sperm concentration is set at $100 \times 10^{6} / \mathrm{ml}$. It is, therefore, the interest of this study to cryopreserve goat semen in reduced sperm concentration per $\mathrm{ml}$ without compromising the number of viable sperm after thawing and possibly increase the production of frozen semen straws.

\section{Materials and Methods}

\section{Goat semen collection}

Anglo Nubian bucks ( $\mathrm{n}=5,2-3$ yrs old) from the Small Ruminant Centre at Central Luzon State University, Science City of Munoz, Nueva Ecija Philippines used for breeding purposes and trained for semen collection were the sperm donor. Using an artificial vagina, the semen ejaculates were collected in a conical test tube early in the morning and brought to the laboratory for processing.

\section{Evaluation of the semen ejaculate}

Upon arrival in the laboratory, the semen was evaluated for its physical characteristics. The volume of the semen was measured against the graduated lines in the conical test tube and recorded accordingly. The $\mathrm{pH}$ was determined using Bromthymol blue (BTB) paper or BTB $\mathrm{pH}$ strips. The semen colour was assessed visually and scored as either creamy, light creamy and watery. The semen consistency was assessed as thick or thin in consistency after running an aliquot of the semen along the inner side wall of the test tube. Semen ejaculates that were creamy in colour and thick in consistency were considered for processing.

\section{Microscopic evaluation}

After the physical characteristics of the ejaculates were observed, microscopic evaluation was performed by taking the sperm concentration, gross and individual motility characteristics. Gross motility was performed by putting an aliquot $(10 \mu \mathrm{l})$ of the semen in a prewarmed glass slide and observed for eddies, circular waves and swirls in an inverted Nikon Eclipse Tx10i microscope. Individual motility on one hand was performed next by placing an aliquot of semen and covered with a pre-warmed cover slip. Individual motility was scored based on the motility scoring (Table 1).

Microscopic evaluation was undertaken under medium $(40 \times)$ and high power $(100 \times)$ objectives using the inverted microscope (Nikon Eclipse Tx10i). Visual motility was recorded using the imaging software (NIS elements) and the progressive sperm movement of the sample was recorded and assessed by an experienced technical personnel. Semen samples having a motility score of $\geq 60 \%$ were considered for semen processing, while those not fulfilling the criteria were discarded.

\section{Sperm concentration}

The sperm concentration was determined after dilution of the sperm sample in an RBC pipette at $1: 200$. The sperm were counted in the central large area of the Neumbauer haemocytometer which consists of 25 squares and each square consists of 16 smaller squares. In case, where the sperm from 5 of the 25 squares were counted, the following formula was used:

Sperm concentration per $\mathrm{ml}=\mathrm{n} \times$ dilution factor $\times$ 50,000

$=\mathrm{n} \times 200 \times 50,000$

$=\mathrm{n} \times 10,000,000$

$=\mathrm{n} \times 10^{7}$

\section{Preparation of the Tris-Yolk Glycerol (TYG solution)}

Table 2 showed the composition of Tris buffer solution prepared by weighing the components accordingly one after the other. Table 3 showed the composition of the Tris buffer solution with egg yolk $(5 \% ; \mathrm{v} / \mathrm{v})$ and glycerol (7\%; v/v) addition.

\section{Initial dilution of the semen ejaculate}

Initial dilution at 1:1 ratio of the semen ejaculate with TYG solution was performed at $37^{\circ} \mathrm{C}$. Afterwards, the initially diluted semen ejaculate and the conical tube with TYG solution were placed in a beaker with water at $37^{\circ} \mathrm{C}$. The beaker was gradually allowed to cool till $10-15^{\circ} \mathrm{C}$. While the gradual cooling process was in progress, the volume of TYG solution to be added was computed to obtain a sperm concentration of $100 \times 10^{6} / \mathrm{ml}$.

\section{Experimental treatments}

The sperm concentrations $/ \mathrm{ml}$ used in the study were:

a. Control $=100 \times 10^{6}$

b. Treatment $A=75 \times 10^{6}$

c. Treatment $\mathrm{B}=50 \times 10^{6}$

d. Treatment $\mathrm{C}=25 \times 10^{6}$

\section{Computing for the volume of the TYG solution (Control)}

The volume of the TYG solution added into the ejaculate was computed using the following formula:

$\mathrm{V}=\underline{(\mathrm{A})(\mathrm{B})(\mathrm{C})}-\mathrm{C}$

$\mathrm{D}$

Where:

$\mathrm{V}=$ volume of the TYG solution to be added 
$A=$ sperm concentration of the ejaculate

$\mathrm{B}=$ Percentage motility score

$\mathrm{C}=$ Volume of the ejaculate

$\mathrm{D}=$ Desired final concentration per $\mathrm{ml}$

Given the following numerical values the volume of TYG solution was computed as follows:

$\mathrm{A}=250 \times 10^{7}$

$\mathrm{B}=75 \%$

$\mathrm{C}=1.2 \mathrm{ml}$

$\mathrm{D}=10 \times 10^{7}$ which is equivalent to $100 \times 10^{6}$

By substitution:

$\mathrm{V}=\frac{\left(250 \times 10^{7}\right)(0.75)(1.5 \mathrm{ml})}{10 \times 10^{7}}-1.5 \mathrm{ml}$ $10 \times 10^{7}$

$\mathrm{V}=28.125-1.5 \mathrm{ml}$

$\mathrm{V}=26.625 \mathrm{ml}$

Therefore, the volume of the TYG solution added to the semen ejaculate was $26.625 \mathrm{ml}$ to obtain a desired sperm concentration of $10 \times 10^{7} / \mathrm{ml}$ which is equivalent to $100 \times 10^{6}$ (Control mixture). During the gradual cooling process the control mixture $\left(100 \times 10^{6}\right)$ was prepared by gradual addition of TYG solution until the temperature reaches $10-15^{\circ} \mathrm{C}$.

At the same cooling temperature of $10-15^{\circ} \mathrm{C}$, the various sperm treatment concentrations were prepared from the control mixture by dilution with a TYG solution in separate pre-labelled test tubes A, B and C (Table 4). After the experimental treatments were prepared, they were allowed to cool further at $5^{\circ} \mathrm{C}$ and kept at this temperature for $2 \mathrm{~h}$.

\section{Vapour freezing of the straws and storage in cryotank}

The semen straws were filled with the diluted semen of varying sperm concentrations as required, placed $4.0 \mathrm{~cm}$ above the level of the $\mathrm{LN}_{2}$ in a styropore box for $7 \mathrm{~min}$, before plunging into the $\mathrm{LN}_{2}$ and stored in cryotank until further use.

\section{Post-thaw motility evaluation}

The straws were thawed in a water bath at $37^{\circ} \mathrm{C}$ for $15 \mathrm{sec}$. Evaluation of post-thaw motility was performed by microscopic visual assessment of the progressive movement under low and high power magnification $(40-100 \times)$. After a visual evaluation by an experienced semen freezing technician, a $\geq 30 \%$ post thaw motility percentage was considered to have passed and kept for cryostorage until further use. The percentage livability (live and dead) and percentage of normal and abnormal cells was likewise determined by microscopy after staining with eosin-nigrosin of the smeared semen samples. A mixture of $1 \%$ eosin and $5 \%$ nigrosin in 3\% sodium citrate as the standard solution was used to stain the semen smear. At least 500 spermatozoa were counted in different microscopic fields. The number of live and dead sperm were counted and the percentage of live and dead sperm were calculated over the total number of sperm observed multiplied by 100 (Mamuad et al., 2004).

\section{Statistical analysis}

The experimental treatments were replicated five times in a Complete Randomized Design. Analysis of variance was performed to evaluate the effect of different sperm concentrations on sperm characteristics such as post-thaw motility percentage, live sperm and abnormal sperm. The differences among treatment means using Tukey's HSD was set at $5 \%(\mathrm{P}<0.05)$ level of significance.

\section{Results and Discussion}

The fresh semen characteristics used in this study were semen volume (ranges from $0.5-2.0 \mathrm{ml}$ ), milky or creamy white in colour without any sign of coagulation or colour abnormalities that may indicate contamination or injury, thick consistency, sperm motility score of 70$80 \%$, mean sperm concentration of $104.4 \pm 18.23 \times 10^{7}$ sperm $/ \mathrm{ml}$ and a mean $\mathrm{pH}$ of 6.56 (Table 5). The differences in the sperm concentration were not affected by the volume of the ejaculates. The smallest volume of ejaculate at $0.5 \mathrm{ml}$ had a sperm concentration of $103.4 \times 10^{7}$ while the highest volume of ejaculate at 2 $\mathrm{ml}$ had a sperm count of $95.2 \times 10^{7}$. The highest sperm concentration obtained was $171.2 \times 10^{7}$ whereas the lowest sperm concentration was $60.4 \times 10^{7}$. Overall, the semen used have a sperm concentration of $6 \times 10^{6}$ $1.7 \times 10^{9} \mathrm{sperm} \mathrm{per} / \mathrm{ml}$. and therefore were considered as a potential source for semen processing.

Thereafter, the semen samples were cryopreserved and stored in the $\mathrm{LN}_{2}$ tank for at least a week before thawing. The post-thaw motility rate obtained were $36.6 \%, 35.4 \%, 27.0 \%$ and $19.2 \%$ for the Control, T-A, $\mathrm{T}-\mathrm{B}$ and $\mathrm{T}-\mathrm{C}$, respectively. The percentage livability observed in the control was $60.6 \%$, whereas in T-A, TB and T-C were $42.8 \%, 39.3 \%$ and $18.7 \%$, respectively. Overall, the post-thaw motility rate of the sperm decreases as the sperm concentration decreases reflecting the observed decreasing percentage livability as the sperm concentration decreases.

In this study, the mean semen volume obtained was $1.04 \mathrm{ml}$, which was higher compared to the semen volume reported in using similar goat breed (AngloNubian; 0.6 $\pm 0.08 \mathrm{ml}$, Bondoc et al., 2007) and in South African indigenous goat $(0.7 \pm 0.08 \mathrm{ml}$; Ramukhithi et al., 2011). In Boer goat, a semen volume of more than $1.5 \mathrm{ml}$ per ejaculate has been reported (Tuli and Holtz, 1995; Sundararaman et al., 2007). In some cases, however, even using similar goat breed had some 
Table 1: Scoring system for the motility of sperm cells*

\begin{tabular}{|c|c|c|}
\hline Motility (\%) & Grade & Characteristics \\
\hline $91-100$ & Excellent motility & $\begin{array}{l}90 \% \text { or more of the spermatozoa are very rigorous in motion. Swirls caused by the } \\
\text { movement of the sperm are extremely rapid and constantly going forward } \\
\text { progressively. }\end{array}$ \\
\hline $76-90$ & Very good motility & $\begin{array}{l}\text { Approximately } 75-90 \% \text { of the spermatozoa is in vigorous rapid motion. Waves and } \\
\text { eddies form rapidly but lesser as in excellent motility. }\end{array}$ \\
\hline $60-75$ & Good motility & $\begin{array}{l}\text { About } 60-75 \% \text { of the spermatozoa is in motion. Motion is vigorous but waves and } \\
\text { eddies formed moved slowly across the field of vision. }\end{array}$ \\
\hline $40-59$ & Fair motility & $\begin{array}{l}\text { From } 40-55 \% \text { of the sperm is in motion. The movements are largely vigorous or eddies } \\
\text { are formed. }\end{array}$ \\
\hline$<40$ & Poor motility & Less than $40 \%$ of the sperm is in motion. The motion is not progressive but mostly \\
\hline 0 & Zero motility & weak and oscillary. No recognizable movements of the sperm. \\
\hline
\end{tabular}

*(Mamuad et al., 2004).

Table 2: Composition of Tris-buffer solution

\begin{tabular}{lcc}
\hline Chemicals/Reagents & $\mathrm{mM}$ & $\mathrm{g} / 100 \mathrm{ml}$ \\
\hline Tris hydroxymethylamino methane & 320.0 & 3.875 \\
Sodium citrate & 10.0 & 2.125 \\
Fructose & 3.0 & 0.625 \\
Raffinose & 8.0 & 0.535 \\
Distilled water & - & $100 \mathrm{ml}$ \\
\hline
\end{tabular}

Table 3: Composition of Tris-buffer solution with egg yolk and glycerol

\begin{tabular}{lcc}
\hline Chemicals/ Reagents & $\begin{array}{c}100 \mathrm{ml} \\
\text { preparation }\end{array}$ & $\begin{array}{c}\text { Final } \\
\text { concentration } \\
\text { in Tris-buffer } \\
\text { solution }\end{array}$ \\
\hline Tri-buffer solution & $88.0 \mathrm{ml}$ & $88.0 \%(\mathrm{v} / \mathrm{v})$ \\
Glycerol & $7.0 \mathrm{ml}$ & $7.0 \%(\mathrm{v} / \mathrm{v})$ \\
Egg yolk & $5.0 \mathrm{ml}$ & $5.0 \%(\mathrm{v} / \mathrm{v})$ \\
Antibiotic $(10 \mathrm{mg} / \mathrm{ml}$ stock) & $100 \mu \mathrm{l}$ & \\
\hline
\end{tabular}

Table 4: Dilution of the control mixture with TYG solution to obtain the experimental treatments

\begin{tabular}{lccc}
\hline $\begin{array}{l}\text { Sperm } \\
\text { concentration } \\
(\text { sperm } / \mathrm{ml})\end{array}$ & $\begin{array}{c}\text { Control } \\
\text { treatment } \\
\text { mixture } \\
\text { volume }\end{array}$ & $\begin{array}{c}\text { Dilute with } \\
\text { TYG solution }\end{array}$ & Volume \\
\hline $\begin{array}{l}\text { Control } 100 \times 10^{6} \\
\text { Treatment A (T-A) }\end{array}$ & $10.0 \mathrm{ml}$ & - & $10 \mathrm{ml}$ \\
$\begin{array}{l}75 \times 10^{6} \\
\text { Treatment (T-B) } \\
50 \times 10^{6}\end{array}$ & $7.5 \mathrm{ml}$ & $2.5 \mathrm{ml}$ & $10 \mathrm{ml}$ \\
$\begin{array}{l}\text { Treatment (T-C) } \\
25 \times 10^{6}\end{array}$ & $2.5 \mathrm{ml}$ & $5.0 \mathrm{ml}$ & $10 \mathrm{ml}$ \\
\hline
\end{tabular}

Table 5: Fresh semen characteristics*

Goat Mean sperm Mean sperm Mean sperm $\mathrm{pH}$

No. volume $(\mathrm{ml})$ motility $(\%)$ concentration

\begin{tabular}{ccccc} 
& & \multicolumn{3}{c}{$\left(\mathrm{n} \times 10^{7}\right)$} \\
\hline 1 & 1.0 & 70 & 91.6 & 6.6 \\
2 & 2.0 & 80 & 95.2 & 6.6 \\
3 & 0.5 & 70 & 103.4 & 6.4 \\
4 & 0.9 & 80 & 171.2 & 6.6 \\
5 & 0.8 & 80 & 60.4 & 6.6 \\
Mean & 1.04 & 76 & 104.4 & 6.56 \\
\hline
\end{tabular}

*Mean values were taken from 5 replicates of each buck used for semen collection. differences in semen volume during ejaculation as influenced by age and feeding system (Dombo, 2002; Almeida et al., 2007; Daramola et al., 2007). Semen volume was also affected by both the physiological status and genetic effects of the bucks (Webb et al., 2004; David et al., 2007). Also, breed differences contribute to variability in semen volume of buck (Choe et al., 2006) as in the case of Korean native goats with semen volume of $2.1 \pm 1.0 \mathrm{ml}$.

The sperm cell motility of $70 \%$ and above obtained in this study was acceptable as it was within the range considered of high quality (Yamashiro et al., 2006) compared to the sperm cell motility of $62.5 \%$ as earlier reported using Saanen goats (Nur et al., 2005). Also, the sperm cell concentration of $104.4 \times 10^{7} / \mathrm{ml}$ observed in Anglo-Nubian goat used was higher than the sperm cell concentrations $\left(116.7 \times 10^{6}-663.6 \times 10^{6} / \mathrm{ml}\right)$ reported in South African indigenous goat and Gorno Altai (Dombo, 2002; Ramukhithi et al., 2011) but lower compared to sperm concentration of $3 \times 10^{9} / \mathrm{ml}$ (Tuli and Holtz, 1995; Sundararaman et al., 2007) to $4.7 \times 10^{9} / \mathrm{ml}$ (Hidalgo et al., 2006) in Florida goats. Some factors considered contributory to the differences observed in this study and other related studies are, the breed used, nutrition, system used for collection and evaluation, age of buck and time of the year (breeding vs non-breeding season) (Gacitua and Arav, 2005; Jimenez et al., 2005; Bester, 2006; Daramola et al., 2006; Zarazaga et al., 2009).

The normal $\mathrm{pH}$ of mammalian semen ranges from 7.2-7.8 (Prins, 1999), and was reported to be most favourable for sperm cell motility (Molinia et al., 1994; Purdy, 2006). In this study, an acidic $\mathrm{pH}$ of 6.56 was obtained following collection through the use of an artificial vagina early in the morning. Similarly, a $\mathrm{pH}$ of 6.4 was observed in South African indigenous goat when using an electro-ejaculator (Ramukhithi et al., 2011). The use of electro-ejaculator stimulates the buck to release acidic urine, which contaminates the semen, thus reducing the semen $\mathrm{pH}$ (Jimenez et al., 2008; Moreno et al., 2009). In this study, the reasons for having an acidic semen remained unclear. 
Moreover, sperm sample with concentrations ranging from $8-50 \times 10^{7}$ sperm $/ \mathrm{ml}$ could be frozen successfully with reasonable fertility (Purdy, 2006). In this study, the mean sperm concentration obtained was $104.4 \pm 18.23 \times 10^{7} / \mathrm{ml}$, thus regarded as useful for cryopreservation studies, although our main interest was on the cryopreservation of buck semen with reduced sperm concentration. The results showed a decrease in post-thaw motility and livability as the sperm concentration decreased. These findings are in agreement with Kozdrowski et al.. (2007) reporting more or less than $30 \%$ sperm cell motility, but lower than the sperm cell motility of $50 \%$ recommended in goat (Biswas et al., 2002). Some factors that may have influenced the post-thaw motility and livability of buck semen used include, a) $p H$ - acidic semen usually results from sperm cell apoptosis that occur during cryopreservation due to toxic substances secreted during death of other sperm cells (Bester, 2006; Uysal and Bucak, 2009), b) the presence of egg yolk in the cryopreservation diluents - if neat semen (as in the case of this study) is added to egg yolk media, the egg yolk coagulate and the sperm may die due to an enzyme of bulbourethral origin named egg yolk-coagulating enzyme (EYCE). This acts as a catalyst that hydrolyzes egg yolk lecithin into fatty acids and lysolecithin causing the sperm membranes to be more fusogenic thereby inducing the acrosome reaction (Upreti et al., 1999) and chromatin decondensation (Sawyer and Brown, 1995), which is toxic to the sperm, c) sperm dilution/concentration - to achieve a high fertility rate using the lowest number of sperm for insemination, it is important that the semen sample be diluted properly so that sufficient numbers of sperm and diluents are available to accommodate the cells in an insemination straw. Dilution rates of 1:1-1:23 (v/v; semen to diluent) have been used successfully (Ritar et al., $1990 \mathrm{a \& b}$ ). It is suggested that a better way of diluting semen should be based on sperm concentration for comparison purposes, d) straw size and freezing height above the $L N_{2}$ - when using $0.5 \mathrm{ml}$ straws, it should be frozen 4 $\mathrm{cm}$ above $\mathrm{LN}_{2}$ for $5 \mathrm{~min}$ before plunging into $\mathrm{LN}_{2}$, while $0.25 \mathrm{ml}$ straws should be placed $16 \mathrm{~cm}$ above the $\mathrm{LN}_{2}$ for $2 \mathrm{~min}$, lowered to $4 \mathrm{~cm}$ for $3 \mathrm{~min}$ before plunging into the $\mathrm{LN}_{2}$ for storage (Chemineau et al., 1991) though 4-5 cm above $\mathrm{LN}_{2}$ for $4-5 \mathrm{~min}$ also had acceptable results (Gravance et al., 1997; Leboeuf et al., 2000). In this study, the straws were held at $4 \mathrm{~cm}$ in a styropore for $7 \mathrm{~min}$, before plunging into the $\mathrm{LN}_{2}$, e) diluents $\mathrm{pH}$ and concentration of buffering additives oxygen uptake of goat sperm is maximal between $\mathrm{pH}$ $7.2-7.5$ and sperm cell motility is optimal between 7.0 7.2 , indicating that goat sperm survival in vitro should be 7.2 (Fukuhara and Nishikawa, 1973). That, increasing the medium $\mathrm{pH}$ from 7-8 stimulates about $50 \%$ of cauda epididymal sperm to become motile, indicating a sensitivity of the sperm to $\mathrm{pH}$ fluctuation (Jaiswal and Majumder, 1998). Also, increasing intracellular $\mathrm{pH}$ activates downstream or parallel pathways that activate protein kinase A, an indicator of capacitation in mammalian sperm cells (Visconti and Kopf, 1998). In this study, the diluents $\mathrm{pH}$ was mistakenly not taken, a critical information that might have contributed on the observed reduced sperm motility post-thawing. On the other hand, post-thaw motility was reported greater with the Tris buffer at concentrations ranging from $350-450 \mathrm{mM}$ combined with 21,42 or $62 \mathrm{mM}$ glucose $(33 \%)$ or fructose $(33 \%)$. The addition of lactose $(29 \%)$ or raffinose $(17 \%)$ resulted in lower percentages of motile cells (Salamon and Ritar, 1982). Similarly, in this study, a combination of fructose $(3 \mathrm{mM})$ and raffinose $8(\mathrm{mM})$ resulted in a reduced sperm motility post thawing. It was suggested that for successful cryopreservation of buck semen, the sugar concentrations should range from $0-62.4 \mathrm{mM}$ when combined with Tris, that monosaccharides offer greater cryoprotective effects than disaccharides (Molinia et al., 1994), f) choice of sugar(s) in the cryopreservation diluents-goat sperm readily utilizes fructose, glucose, lactose and other sugars for respiration, osmotic balance and cryprotection. Of these, fructose has the greatest molar concentration in neat goat semen and is the primary substrate for glycolysis in goat seminal plasma making it the most logical sugar of choice to include in the medium (Pellicer-Rubio et al., 1997; Aboagla and Terada, 2003). Likewise, glucose is an excellent substrate in goat sperm metabolism and essential for providing energy for the sperm cells to function in a normal physiological manner (Fukuhara and Nishikawa, 1973; Corteel, 1974) and, g) choice of cryoprotectants- the use of penetrating cryoprotectant (glycerol at 6\%) alone resulted in high percentage motility (35\%) post thawing, but when combined with other cryoprotectants (eg., dimethyl sulfoxide at 5.9\%) resulted in 45\% progressive motility (Kundu et al., 2001). In this study, the inclusion of non-penetrating cryprotectants in the cryopreservation medium (e.g., egg yolk at 5\%) together with glycerol at $7 \%$ afforded a progressive motility and liveability of $35.4 \pm 2.04 \%$ and $42.86 \pm 1.83 \%$, respectively when using $75 \times 10^{6}$ sperm $/ \mathrm{ml}$ concentration.

\section{Conclusion}

The volume of information provided in this study could be used for the improvement of cryopreservation procedures in goat semen. That, it is possible to cryopreserve goat semen in a reduced concentration of $50-75 \times 10^{6}$ sperm $/ \mathrm{ml}$ and used for artificial insemination, in vitro fertilization studies and for eventual embryo production, given the fact that it can result in almost $40 \%$ sperm livability post-thawing. 


\section{References}

Aboagla EME, Terada T (2003) Trehalose-enhanced fluidity of the goat sperm membrane and its protection during freezing. Biol Reprod 69: 12451250.

Almeida AM, Schwalbach LMJ, Cardoso LA, Greyling JPC (2007) Scrotal, testicular and semen characteristics of young Boer bucks fed winter veld hay: The effect of nutritional upplementation. Small Rumin Res 73: 216-220.

Beltran MAG, Atabay EP, Atabay EC, Cruz EM, Aquino FP, Cruz LC (2013) Optimized extenders for cryopreservation of buck semen for artificial insemination. Phil J Vet Anim Sci 39: 1-10.

Bester N (2006) Effect of different dietary energy levels on productive and reproductive traits in Dorper rams. [MSc dissertation], Bloemfontein University Free State.

Biswas D, Bari FY, Shamsuddin M, Rahman MM (2002) Determination of glycerol percentages for preserving the Black Bengal buck spermatozoa for long time. Pak J Biol Sci 5: 715-718.

Bondoc OL, Serrano DB, Dela Cruz JF (2007) Prestorage semen test and comparative use of skimmed milk-based extender to preserve semen of Philippine native and Anglo-Nubian goats. Phil J Vet Med 44: 43-50.

Chemineau P, Cagnie Y, Guerin Y, Orgeur P, Vallet JC (1991). Training manual on artificial insemination in sheep and goats. FAO Reproduction and Health Paper. FAO of UN, pp: 115-161.

Choe CY, Kim JG, Cho SR, Son DS, Kim YK, Balasubramanian S, Choe SY, Rho GJ (2006) Influence of seasons, extenders, slow and rapid freezing on seminal characters in Korean native bucks. Rep Domest Anim. 41: 55-60.

Corteel JM (1974) Viability of goat spermatozoa deep frozen with or without seminal plasma;effect of glucose. Ann Biol Anim Biochem Biophys 14: 741-745.

Daramola JO, Adeloye AA, Fayeye TR, Fatoba TA. Soladoye AO (2006) Influence of photoperiods with or without melatonin on spermiograms in West African dwarf bucks. World J Zool 1: 86-90.

Daramola JO, Adeloye AA, Fatoba TA, Soladoye AO (2007) Induction of puberty in West African Dwarf buck kids with exogenous melatonin. Livestock Res Rural Dev 19: 9.

Dombo MH (2002) Seasonal effect on semen quality of Gorno Altai and South African indigenous goats. [MSc dissertation], Pretoria, University of Pretoria.

David I, Druart X, Lagriffoul G, Manfredi E, Christele R, Bodin L (2007) Genetics and environmental effects on semen traits in Lacaune and Menechtete rouse AI rams. Genet Sel Evol 39: 405-419.

Fukuhara R, Nishikawa Y (1973) Effects of pH, sperm concentration, washing and substrate concentration on respiration and motility of goat spermatozoa. Jpn J Zootech Sci 44: 266-270.

Gacitua H, Arav A (2005) Successful pregnancies with directional freezing of large volume buck semen. Theriogenology 63: 931-938.

Gravance CG, White C, Robertson KR, Champion ZJ, Casey PJ (1997) The effects of cryopreservation on the morphometric dimensions of caprine sperm heads. Anim Reprod Sci 49: 37-43.

Hidalgo M, Rodriguez I, Dorado J (2006) Influence of staining and sampling procedures on goat semen morphometry using the sperm class analyzer. Theriogenology 66: 996-1003.

Jaiswal BS, Majumder GC (1998) Biochemical parameters regulating forward motility initiation in vitro in goat immature epididymal spermatozoa. Reprod Fertil Dev 10: 299-307.

Jimenez F, Puchades S, Gadea J, Vicente JS, Viudesde-Castro MP (2005) Effect of semen collection method on pre- and post- thaw Guirra ram spermatozoa. Theriogenology 64: 1756-1765.

Jimenez F, Vicente JS, Viudes-de-Castro MP (2008) Seminal plasma composition from ejaculates collected by artificial vagina and electroejaculation in Guirra ram. Rep Domest Anim 43: 403-408.

Kozdrowski R, Dubiel A, Bielas W, Dzieciol M (2007) Two protocols of cryopreservation of goat semen with the use of CASA system. Acta Vet Scand 76: 601-604.

Kundu CN, Das K, Majumder GC (2001) Effect of amino acids on goat cauda epididymal sperm cryopreservation using a chemically defined model system. Cryobiology 41: 21-27.

Leboeuf B, Restall B, Salamon S (2000) Production and storage of goat semen for artificial insemination. Anim Reprod Sci 62: 113-141.

Mamuad FV, Venturina EV, Saito H (2004) Collection, processing and handling of buffalo semen. Water Buffaloes and Beef Cattle Improvement Project. A joint-JICA Assisted Project of the Philippine Carabao Center and the Bureau of Animal Inductry, Philippines.

Molinia FC, Evans G, Quintana C, Maxwell WMC (1994) Effect of monosaccharides and disaccharides in Tris-based diluents on motility, acrosome integrity and fertility of pellet frozen ram spermatozoa. Anim Reprod Sci 36: 113-122.

Moreno JS, Coloma MA, Dorado J, Pastor AP, Gomez F, Vega R, Brunet A, Sebastian LA (2009) Cryopreservation of Spanish ibex sperm obtained by electro ejaculation outside the rutting season. Theriogenology 71: 1253-1260. 
Nur Z, Dogan I, Gunay U, Soylu MK (2005) Relationship between membrane integrity and other semen quality characteristics of Saanen goat bucks. B Vet Pulawy 49: 183-187.

Pellicer-Rubio M.T, Magallon T, Combarmous Y (1997) Deterioration of goat sperm viability in milk extenders is due to a bulbourethral 60-kilodalton glycoprotein with triglyceride lipase activity. Biol Reprod 57: 1023-1031.

Ramukhithi FV, Nedambale TL, Sutherland B, Lehloenya KC (2011) Cryopreservation of South African indigenous goat semen. African J Biotech 10: 17898-17902.

Ritar AJ, Ball PD, O'May PJ (1990a) Artificial insemination of Cashmere goats. Reprod Fertil Dev 2: 377-384.

Ritar AJ, Ball PD, O’May PJ (1990b) Examination of methods for the deep freezing of goat semen. Reprod Fertil Dev 2: 27-34.

Salamon S, Ritar AJ (1982) Deep freezing of Angora goat semen: effects of diluents composition and method and rate of dilution on survival of spermatozoa. Aust J Biol Sci 35: 295-303.

Sawyer DE, Brown DB (1995) The use on an in vitro sperm activation assay to detect chemically induced damage of human sperm nuclei. Reprod Toxicol 9: 351-357.

Sundararaman MN, Kalatharan J, Edwin MJ (2007) Attempts to achieve semen collections from incapacitated Boer bucks by electro ejaculation. Asian J Anim Vet Adv 2: 244-246.

Tuli RK, Holtz W (1995). Effect of season on the freezability of Boer goat semen in the Northern temperate zone. Theriogenology 43: 1359-1363.

Prins GS (1999). In: Knobil E, Neill JD (Eds), Encyclopedia of Reproduction. 4 Academic Press, San Diego, USA, pp: 360-367.

Purdy PH (2006). A review on goat sperm cryopreservation. Small Rumin Res 63: 215-225.

Uysal O, Bucak MN (2009) The role of different trehalose concentrations and cooling rates in freezing of ram semen. Ankara Univ Vet Fak Derg 56: 99-103.

Visconti PE, Kopf GS (1998) Regulation of protein phosphorylation during sperm capacitation. Biol Reprod 59: 1-6.

Webb EC, Dombo MH, Roets M (2004) Seasonal variation in semen quality of Gorno Altai cashmere goats and South African indigenous goats. S Afr J Anim Sci 34: 240-243.

Yamashiro H, Kumamoto K, Wang H, Yamashita Y, Terada $T$ (2006) Effect of semen collection in extender solution on the characteristics of goat spermatozoa. J Reprod Dev 52: 397-406.

Zarazaga LA, Guzman JL, Dominguez C, Perez MC, Prieto R (2009) Effects of season and feeding level on reproductive activity and semen quality in Payoya buck goats. Theriogenology 71: 13161325. 